\title{
Genetic variation at marker loci and in quantitative traits in natural populations of Arabidopsis thaliana
}

\author{
HELMI KUITTINEN*, ANU MATTILA $†$ \& OUTI SAVOLAINEN \\ Department of Biology, University of Oulu, Oulu, 90570 Finland
}

\begin{abstract}
Genetic variation was studied in quantitative traits and molecular markers in six natural Scandinavian populations of Arabidopsis thaliana. Only two of the populations had several molecular marker haplotypes and significant between-family variance components in quantitative traits. There was no genetic variation in the other four populations. The differentiation between the populations was high in both molecular markers and quantitative traits, with $F_{\mathrm{ST}}$ estimates of above 0.60 in almost all traits. The patterns of variation of the neutral markers and morphological and phenological traits were consistent in all the analyses, as opposed to what has been found in predominantly outcrossing species. The general picture of the level and distribution of genetic variance agrees with the information from other predominantly inbreeding species.
\end{abstract}

Keywords: allozymes, Arabidopsis thaliana, microsatellites, population structure, quantitative variation.

\section{Introduction}

The level and distribution of genetic variation in inbreeding species has long been an object for both theoretical and experimental considerations. In surveys of allozyme variation, the total amount of variation in selfing species is, on average, almost as high as that in outcrossing species, but the relative amount of variability among populations is larger in selfers (Hamrick \& Godt, 1990). There are extensive differences in gene diversity and in effective population size among populations in inbreeders, as opposed to outbreeders (Schoen \& Brown, 1991).

Quantitative variation is also expected to be mainly between populations rather than within, because of restricted gene flow and potential for local adaptation (Hillel et al., 1973). Recently, Charlesworth \& Charlesworth (1995) showed that the level of variability in quantitative traits is predicted to be lower in populations of inbreeders compared to outbreeders under different models that account for the maintenance of quantitative variation. Reduction of the effective population size through repeated colonizing and extinction events (Schoen \& Brown, 1991), selective sweeps caused by hitch-

*Correspondence. E-mail: helmi.kuittinen@oulu.fi

†Present address: Foundation for Tree Breeding, Helsinki, Finland. hiking (Hedrick, 1980) and background selection (Charlesworth et al., 1993) can additionally reduce the amount of genetic variation in inbreeders. However, empirical results do not always agree with these predictions (Charlesworth \& Charlesworth, 1995).

Relatively few empirical studies combine marker gene and quantitative information. Congruence between information from neutral marker genes and quantitative traits may allow conclusions regarding the role of selection on the population differences (Lande, 1992). Several recent studies use this principle (e.g. Prout \& Barker, 1993; Podolsky \& Holtsford, 1995), but studies including selfing species are rare (Price et al., 1984).

Arabidopsis thaliana (L.) Heynh. is an inbreeding annual plant that has long been used as a model organism in plant genetics and physiology (see Meyerowitz \& Somerville, 1994). Most advances have been made in developmental genetics, physiology and cell biology, and much less research has been undertaken in the field of population genetics (reviewed in Meyerowitz \& Somerville, 1994). This is partly because selfing species have not recently gained as much interest as outcrossing species, despite the early progress (Allard et al., 1968). Population genetic studies of selfing species would, however, certainly profit from using this model 
species with a large amount of physiological and molecular genetic information available. On the other hand, background information from the genetic and ecological aspects of natural populations would provide an improved setting for interpreting results in other fields.

Here we combine marker and quantitative trait approaches in a study of six Scandinavian natural populations of $A$. thaliana. We assess the levels of quantitative variation and the distribution of the variation within and between populations. In addition, we study the genetic composition of the populations with allozymes and microsatellites. We also compare the level of population differentiation in the marker genes to that in quantitative traits.

\section{Materials and methods}

Arabidopsis thaliana is an annual, nearly completely selfing (Abbot \& Gomez, 1989), brassicaceous plant. The main distribution is in the western part of Eurasia, but $A$. thaliana also occurs in Central Asia and the Middle East. It has been spread by man to South and East Africa, Japan, Australia and North America (Jalas, 1965; Hultén \& Fries, 1986). In Scandinavia the species has its northernmost distribution. The natural habitats of $A$. thaliana are open cliffs, but it also occupies other dry habitats like sandy bluffs, roadsides and railway tracks, as well as borders of paths and gardens. In Finland $A$. thaliana is usually a winter annual (Jalas, 1965). It germinates in the autumn, overwinters as a rosette and flowers early in the spring. Summer annuals that complete their life cycle in the same season, are rare in the north but common in Central Europe.

\section{Populations}

Seeds of one Danish, one Swedish and four Finnish populations were collected in the field in late May-early June in 1989 or 1990 . Thirty plants that had produced at least three siliques were chosen randomly from each population. All ripe siliques were collected from each plant and the dried seeds of the family (progeny of an individual plant) were mixed. Before using the seeds for experiments they were stored first on the shelf and then in a cold room. During all the experiments the germination of the seeds was good. A list of the populations, and a description of their habitats is presented in Table 1 .

\section{Quantitative experiments}

The data on quantitative variation were collected in two experiments. Four populations, Broborg, Tvärminne, Paijärvi and Nurmes, were used in the first

Table 1 Description of the study populations of Arabidopsis thaliana. The sizes of the populations were classified as small (fewer than 100 flowering individuals), medium (100-1000 flowering individuals) or large (more than 1000 flowering individuals). All habitats are located between 0 and $100 \mathrm{~m}$ above sea level

\begin{tabular}{|c|c|c|c|}
\hline Population & Location & Habitat & Size \\
\hline $\begin{array}{l}\text { Ruds Vedby } \\
\text { (Denmark) }\end{array}$ & $\begin{array}{l}11^{\circ} 22^{\prime} \mathrm{E} \\
55^{\circ} 33^{\prime} \mathrm{N}\end{array}$ & $\begin{array}{l}\text { Along a railway track. } \\
\text { Other vegetation was rather } \\
\text { scarce and low }\end{array}$ & Medium \\
\hline $\begin{array}{l}\text { Naantali } \\
\text { (Finland) }\end{array}$ & $\begin{array}{l}22^{\circ} 5^{\prime} \mathrm{E} \\
60^{\circ} 40^{\prime} \mathrm{N}\end{array}$ & $\begin{array}{l}\text { Sandy soil beside a railway } \\
\text { track in the harbour. Other } \\
\text { vegetation was rather scarce }\end{array}$ & Large \\
\hline $\begin{array}{l}\text { Nurmes } \\
\text { (Finland) }\end{array}$ & $\begin{array}{l}29^{\circ} 10^{\prime} \mathrm{E} \\
63^{\circ} 32^{\prime} \mathrm{N}\end{array}$ & $\begin{array}{l}\text { Sandy soil beside a } \\
\text { railway track. Other } \\
\text { vegetation was abundant }\end{array}$ & Small \\
\hline $\begin{array}{l}\text { Broborg } \\
\text { (Sweden) }\end{array}$ & $\begin{array}{l}17^{\circ} 57^{\prime} \mathrm{E} \\
59^{\circ} 45^{\prime} \mathrm{N}\end{array}$ & $\begin{array}{l}\text { Ruins of an ancient } \\
\text { castle. Other vegetation } \\
\text { was very scarce }\end{array}$ & Medium \\
\hline $\begin{array}{l}\text { Tvärminne } \\
\text { (Finland) }\end{array}$ & $\begin{array}{l}23^{\circ} 14^{\prime} \mathrm{E} \\
59^{\circ} 51^{\prime} \mathrm{N}\end{array}$ & $\begin{array}{l}\text { Open cliff next to a small } \\
\text { road }\end{array}$ & Medium \\
\hline $\begin{array}{l}\text { Paijärvi } \\
\text { (Finland) }\end{array}$ & $\begin{array}{l}27^{\circ} 11^{\prime} \mathrm{E} \\
60^{\circ} 40^{\prime} \mathrm{N}\end{array}$ & $\begin{array}{l}\text { A sandy road bank. No } \\
\text { other vegetation }\end{array}$ & Medium \\
\hline
\end{tabular}


experiment. From each population four seeds from 30 random families were sown in pots filled with a 1:3:3 mixture of sand, soil and peat. The populations and families were randomized in four blocks. The plants were grown in a growth room in continuous light (10000 lux) produced with Osram Power Star HQI-T $400 \mathrm{~W} / \mathrm{DH}$ lamps. The temperature was $25^{\circ} \mathrm{C}$ and the relative humidity 80 per cent.

The following traits were scored: the number of days until the emergence of cotyledons, the number of days until the emergence of the 4th, 7th, 11th and 15 th leaf (counting the cotyledons as 1st and 2nd leaf) and the average number of days needed for the formation of one leaf (growth rate $=$ (date of emergence of the 15th leaf-date of emergence of the 4th leaf)/11). The days were counted from the day of sowing.

The second experiment was conducted using three populations, Ruds Vedby, Naantali and Nurmes. From each population four seeds from 18 random families were sown in pots filled with a 1:1 mixture of peat and vermiculite. The populations and the families were randomized in two blocks. The pots were kept at a temperature of $4^{\circ} \mathrm{C}$ for 3 weeks to ensure flowering, after which they were transferred to a greenhouse. The plants were grown in the greenhouse from 15 March until 24 May, when all the plants had started flowering. The temperature fluctuated around $20^{\circ} \mathrm{C}$, depending on the ambient temperature, and was lower at night. In addition to natural light, the plants received $10 \mathrm{~h}$ a day of supplemental illumination by sodium lamps.

The following measurements were taken at the time that the first flower opened: leaf index (leaf length divided by width, the mean of two largest leaves was used in calculations); size of the rosette (the mean of two measures at right angles); number of rosette leaves; number of cauline leaves; and days to flowering counted from the day of transfer to the greenhouse.

\section{Allozyme variation}

Allozyme variation was studied in four populations, Nurmes, Broborg, Tvärminne and Paijärvi by starch gel electrophoresis. Three individuals from 20 random families were used for the analysis. Ten different enzyme systems were analysed: aconitase (ACO, EC 4.2.1.3); glutamate dehydrogenase (GDH, EC 1.4.1.2); glutamic-oxaloacetic transaminase (GOT, EC 2.6.1.1); isocitrate dehydrogenase (IDH, EC 1.1.1.41); leucine aminopeptidase (LAP, EC 3.4.11.1); malate dehydrogenase (MDH, EC 1.1.1.37); 6-phosphogluconate dehydrogenase
(6-PGD, EC 1.1.1.43); phosphoglucoisomerase (PGI, EC 5.3.1.9); phosphoglucomutase (PGM, EC 5.4.2.2); and shikimate dehydrogenase (SHDH, EC 1.1.1.25). For ACO, GDH, IDH, MDH, 6-PGD and SHDH analysis the gels were run on Tris-citrate (electrode buffer: $0.14 \mathrm{M}$ Tris, $0.06 \mathrm{M}$ citric acid, $\mathrm{pH}$ 7.0; gel buffer: 1:16 dilution of the electrode buffer), for GOT and LAP on Ashton (electrode buffer: $0.05 \mathrm{M} \mathrm{LiOH}, 0.19 \mathrm{M}$ boric acid, $\mathrm{pH}$ 8.1; gel buffer: $0.005 \mathrm{M} \mathrm{LiOH}, 0.019 \mathrm{~m}$ boric acid, $0.006 \mathrm{~m}$ citric acid, $0.029_{\mathrm{M}}$ Tris, $\mathrm{pH}$ 8.1), and for PGI and PGM on KA3 (electrode buffer: $0.3 \mathrm{~m}$ boric acid, $\mathrm{pH} 8.5$ adjusted with $\mathrm{LiOH}$; gel buffer: $0.022 \mathrm{M}$ Tris, $\mathrm{pH} 6.8$ adjusted with citric acid) buffer systems. Samples were prepared by grinding a piece of leaf from a 4-week-old plant in $0.1 \mathrm{M}$ Tris- $\mathrm{HCl} 0.1$ per cent mercaptoethanol ( $\mathrm{pH}$ 7.1). Preparation of the gels, electrophoresis and staining of the enzymes was performed with standard methods. The loci revealed by each staining were named according to the mobility of their gene products, so that the locus with the most anodal proteins was named 1, the next 2 and so on. The alleles at each locus were named in the same manner.

\section{Microsatellite variation}

Five microsatellites, nga8, nga76, nga126, nga139 and nga172, developed by Bell \& Ecker (1994) were assayed in the Ruds Vedby, Naantali and Nurmes populations. One individual from 23 families from each population was grown, and DNA was extracted from the leaves with the CTAB method of Rogers \& Bendich (1989). The microsatellites were amplified using primers obtained from Genetic Research (Alabama). The PCR conditions were mainly as described in Bell \& Ecker (1994). For nga76 the stringency of the PCR was lowered for a part of the samples to obtain amplification in all samples. The PCR products were separated on 4 per cent agarose gels, which distinguishes between alleles with at least 2-4 bp length differences (van Treuren et al., 1997). Ethidium bromide $\left(0.5 \mu \mathrm{g} \mathrm{mL}^{-1}\right)$ was added to the gels and the tray buffer to visualize DNA.

Because the exact lengths of the alleles could not be determined, they were named according to their mobilities, so that the most anodal allele was named 1 , the next 2 and so on.

\section{Data analysis}

The normality of the distribution of each quantitative trait was tested using Kolmogorov statistics. Because transformations did not improve the 
normality of the distributions in most traits that were not normally distributed, the original measurements were used for all tests. The data were analysed with a nested ANOVA using the model: trait $=$ mean + block + population + family (within-population) + error. Block, population and family within population were regarded as random effects. Because the block effect was not significant in the first experiment and in the second experiment only in one case, it was discarded from the models in later analyses. In case the trait was not normally distributed, nonparametric Kruskal-Wallis tests were also used to examine the differences between populations and between families within populations to verify the results of $F$-tests. The causal variance components were calculated from expected mean squares according to Falconer (1989).

To estimate the between-family variance components, an analysis of variance was performed in each population separately, using the model: trait $=$ mean + family + error, where family was a random effect.

In a completely selfing species the between-family variance component is an estimate of the total genetic variance $V_{\mathrm{G}}$. The broad-sense heritabilities were estimated as $h^{2}=V_{\mathrm{G}} /\left(V_{\mathrm{G}}+V_{\mathrm{E}}\right)$.

The proportion of quantitative genetic variation between populations $\left(F_{\mathrm{ST}}\right)$ was estimated as $V_{\mathrm{B}} /\left(V_{\mathrm{B}}+V_{\mathrm{G}}\right)$ (Wright, 1969; p. 448). In this method, $V_{\mathrm{G}}$ is assumed to be the additive genetic variance within populations. Because our $V_{\mathrm{G}}$ is the total genetic variation including possible variance components attributable to dominance, epistasis, or maternal effects, the estimate of $F_{\mathrm{ST}}$ may be biased downwards.

As a measure of genetic variability at the allozyme and microsatellite loci, the mean expected heterozygosity for all the loci $\left(H_{\mathrm{e}}\right)$ was calculated. The between-population differentiation was estimated as $F_{\text {ST }}$-values (Weir \& Cockerham, 1984). Their significance was tested with bootstrap tests.

\section{Results}

\section{Within-population variation}

All five microsatellite loci and five out of 12 enzyme loci were polymorphic in the total data set. In four populations (Broborg, Tvärminne, Paijärvi and Nurmes), there was only one haplotype. Variation was found in two populations (Ruds Vedby and Naantali). In the samples of 23 individuals, seven and ten microsatellite haplotypes were found in these populations, respectively. The individuals were homozygous, with the exception of one individual in
Table 2 Sample sizes of Arobidopsis thaliana, expected heterozygosities $\left(H_{\mathrm{e}}\right)$, and their standard deviations (SD $\left.\left(H_{\mathrm{e}}\right)\right)$

\begin{tabular}{llll}
\hline & $N$ & $H_{\mathrm{e}}$ & $\mathrm{SD}\left(H_{\mathrm{e}}\right)$ \\
\hline Broborg & 60 & 0 & \\
Tvärminne & 60 & 0 & \\
Paijärvi & 60 & 0 & \\
Nurmes* & 60 & 0 & \\
Nurmes $\dagger$ & 23 & 0 & \\
Ruds Vedby & 23 & 0.510 & 0.071 \\
Naantali & 23 & 0.435 & 0.049 \\
\hline
\end{tabular}

*Allozymes.

$\nmid$ Microsatellites.

the Naantali population that appeared as a heterozygote at one microsatellite locus. The heterozygote may be a result of a cross-fertilization, because both alleles occur in the population, but a new mutation cannot be excluded.

The distribution of the haplotypes was far from even in both Ruds Vedby and Naantali. One haplotype was represented by about half of the individuals; the other haplotypes were rare. The average expected heterozygosities were, however, high (Table 2).

Quantitative variation followed closely the pattern found at the marker loci (Table 3). The populations which were monomorphic at the marker loci had significant differences between families in only two cases out of 29 possible population $\times$ trait combinations. For the two populations consisting of several haplotypes, the between-family variance component was significant in all traits studied in at least one of them. The nonparametric Kruskal-Wallis test was used to verify the results in cases where the trait was not normally distributed, and the results were similar to $F$-tests in all cases.

\section{Between-population variation}

The populations were differentiated at marker loci in both experiments (Table 4 ). The $F_{\mathrm{ST}^{-}}$-values were high, 1.000 in the first experiment and 0.639 in the second. The $F_{\mathrm{ST}}$-value 1.000 resulted from the fact that all populations were different from each other at least at one locus, whereas there was no withinpopulation variation.

There were significant differences between populations in all but one quantitative trait in experiment 
1 and all traits in experiment 2 (Table 4). The Kruskal-Wallis tests gave similar results for non-normally distributed traits. The $F_{\mathrm{ST}}$-values were high, ranging from 0.290 to the extreme 1.000 in cases where the between-families variance compo-

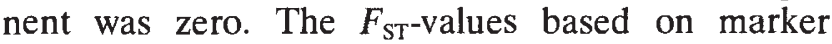
genes and quantitative traits were generally in accordance.

\section{Discussion}

\section{Monomorphic and polymorphic populations in Scandinavia}

The four northernmost $A$. thaliana populations were monomorphic with respect to allozyme and microsatellite loci, whereas the two southernmost populations were polymorphic. In addition, another

Table 3 Between-families $\left(V_{\text {FAM }}\right)$ and error $\left(V_{\mathrm{E}}\right)$ variance components, means, broad-sense heritabilities $\left(h^{2}\right)$ and their standard errors $\left(\mathrm{SD}\left(h^{2}\right)\right)$ for Arabidopsis thaliana. Significance of the between-families variance components was tested with $F$-tests

\begin{tabular}{|c|c|c|c|c|c|c|}
\hline Trait & Population & $V_{\text {FAM }}$ & $V_{\mathrm{E}}$ & Mean & $h^{2}$ & $\operatorname{SD}\left(h^{2}\right)$ \\
\hline \multirow[t]{4}{*}{ Cotyledons } & Broborg & $0.46^{*}$ & 1.93 & 3.9 & 0.19 & 0.11 \\
\hline & Tvärminne & $-0.96 \mathrm{NS}$ & 5.82 & 5.4 & 0.00 & \\
\hline & Paijärvi & $-0.10 \mathrm{NS}$ & 1.53 & 3.9 & 0.00 & \\
\hline & Nurmes & $-0.02 \mathrm{NS}$ & 1.46 & 3.6 & 0.00 & \\
\hline \multirow{4}{*}{ 4-leaf stage } & Broborg & $0.37 \mathrm{NS}$ & 2.63 & 8.8 & 0.12 & 0.09 \\
\hline & Tvärminne & $-1.49 \mathrm{NS}$ & 8.43 & 11.2 & 0.00 & \\
\hline & Paijärvi & $0.47^{* *}$ & 1.39 & 9.1 & 0.25 & 0.14 \\
\hline & Nurmes & 0.04 NS & 2.20 & 8.7 & 0.02 & 0.05 \\
\hline \multirow[t]{4}{*}{ 7-leaf stage } & Broborg & $0.81 \mathrm{NS}$ & 13.10 & 16.9 & 0.06 & 0.07 \\
\hline & Tvärminne & $1.70 \mathrm{NS}$ & 4.81 & 18.4 & 0.26 & 0.26 \\
\hline & Paijärvi & $-1.02 \mathrm{NS}$ & 16.14 & 16.8 & 0.00 & \\
\hline & Nurmes & $-0.70 \mathrm{NS}$ & 12.55 & 16.6 & 0.00 & \\
\hline \multirow[t]{4}{*}{ 11-leaf stage } & Broborg & $1.18 \mathrm{NS}$ & 19.34 & 24.0 & 0.06 & 0.07 \\
\hline & Tvärminne & $0.65 \mathrm{NS}$ & 9.88 & 25.6 & 0.06 & 0.12 \\
\hline & Paijärvi & $-0.44 \mathrm{NS}$ & 9.60 & 22.9 & 0.00 & \\
\hline & Nurmes & $-3.25 \mathrm{NS}$ & 26.75 & 24.0 & 0.00 & \\
\hline \multirow[t]{4}{*}{ 15-leaf stage } & Broborg & $-1.30 \mathrm{NS}$ & 25.09 & 30.7 & 0.00 & \\
\hline & Tvärminne & 0.99 NS & 14.08 & 32.3 & 0.06 & 0.13 \\
\hline & Paijärvi & $-0.76 \mathrm{NS}$ & 11.14 & 29.4 & 0.00 & \\
\hline & Nurmes & $-2.64 \mathrm{NS}$ & 20.47 & 30.6 & 0.00 & \\
\hline \multirow{4}{*}{ Growth rate (days/leaf) } & Broborg & $-0.012 \mathrm{NS}$ & 0.167 & 2.00 & 0.00 & \\
\hline & Tvärminne & 0.014 NS & 0.056 & 1.95 & 0.19 & 0.31 \\
\hline & Paijärvi & $-0.012 \mathrm{NS}$ & 0.098 & 1.84 & 0.00 & \\
\hline & Nurmes & $-0.025 \mathrm{NS}$ & 0.159 & 1.99 & 0.00 & \\
\hline \multirow[t]{3}{*}{ Flowering time (days) } & Ruds Vedby & $4.77 * * *$ & 8.38 & 62.4 & 0.36 & 0.29 \\
\hline & Naantali & $4.95^{* *}$ & 10.57 & 58.6 & 0.32 & 0.28 \\
\hline & Nurmes & $-0.82 \mathrm{NS}$ & 7.31 & 55.6 & 0.00 & \\
\hline \multirow{3}{*}{ Number of cauline leaves } & Ruds Vedby & $2.70^{* * *}$ & 2.09 & 7.17 & 0.56 & 0.36 \\
\hline & Naantali & $0.33 \mathrm{NS}$ & 2.53 & 4.83 & 0.12 & 0.17 \\
\hline & Nurmes & $-0.05 \mathrm{NS}$ & 0.91 & 3.80 & 0.00 & \\
\hline \multirow{3}{*}{ Number of rosette leaves } & Ruds Vedby & $12.8^{* *}$ & 29.5 & 29.3 & 0.30 & 0.27 \\
\hline & Naantali & $10.1^{*}$ & 28.0 & 21.0 & 0.27 & 0.25 \\
\hline & Nurmes & 0.4 NS & 6.6 & 14.7 & 0.06 & 0.12 \\
\hline \multirow[t]{3}{*}{ Rosette size (mm) } & Ruds Vedby & $67.2 \mathrm{NS}$ & 511 & 60.4 & 0.12 & 0.17 \\
\hline & Naantali & $238.6^{*}$ & 577 & 70.8 & 0.29 & 0.27 \\
\hline & Nurmes & 24.6 NS & 712 & 57.1 & 0.03 & 0.10 \\
\hline \multirow[t]{3}{*}{ Leaf index } & Ruds Vedby & $0.0009^{*}$ & 0.0029 & 0.35 & 0.24 & 0.25 \\
\hline & Naantali & $0.0014 * * *$ & 0.0011 & 0.27 & 0.55 & 0.40 \\
\hline & Nurmes & $-0.0000 \mathrm{NS}$ & 0.0028 & 0.33 & 0.00 & \\
\hline
\end{tabular}

NS $P>0.05,{ }^{*} 0.01 \leq P<0.05,{ }^{* *} 0.001 \leq P<0.01,{ }^{* * *} P<0.001$. 
northern population, Karhumäki, near lake Onega in Russian Karelia, consists of only one microsatellite multilocus genotype (data not shown). The analysis of quantitative traits was concordant with the results from marker studies. There was withinpopulation variation only in the two southern populations, Naantali and Ruds Vedby. There were significant differences between families in the other populations in only two population $\times$ charac $^{+}$er combinations out of 29 , but these can be accounted for by either chance or maternal effects.

The habitat did not give many cues to the existence or lack of variation in the populations. The polymorphic population, Naantali, is situated in a harbour, and may be a target of a constant gene flow. None of the populations was known to be under regular cutting or other severe disturbance, which would lead to repeated extinction and recolonizing events. In earlier studies railway populations have been more variable than populations from gardens (Jones, 1971a).

The first experiment recorded no variation, the second found some. The Nurmes population was included in both, and the results from this were concordant. The differences between the two experiments are thus not likely to be caused just by the experimental conditions.

Population genetic studies have earlier been carried out in central populations of the species distribution (Dobrovolná, 1969; Jones, 1971a,b,c;

Table 4 Partitioning of the quantitative variance in Arabidopsis thaliana into components attributable to populations $\left(V_{\mathrm{POP}}\right)$, families within populations $\left(V_{\mathrm{FAM}}\right)$ and error $\left(V_{\mathrm{E}}\right)$. The significance of the variance components was tested with $F$-tests. The proportion of the total variance is given under each variance component. Negative variance components are taken as zero. $F_{\mathrm{ST} \text {-values based }}$ on quantitative traits and molecular markers are shown. The significance of the

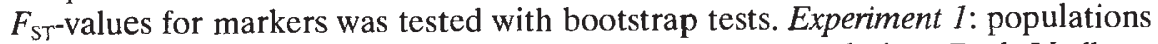
Broborg, Tvärminne, Paijärvi, Nurmes; Experiment 2: populations Ruds Vedby, Naantali, Nurmes

\begin{tabular}{|c|c|c|c|c|}
\hline & $\mathrm{V}_{\mathrm{POP}}$ & $V_{\mathrm{FAM}}$ & $V_{\mathrm{E}}$ & $F_{\mathrm{ST}}$ \\
\hline \multicolumn{5}{|l|}{ Experiment 1} \\
\hline Cotyledons & $\begin{array}{l}0.29^{* * *} \\
13 \%\end{array}$ & $\begin{array}{l}0.15 \mathrm{NS} \\
6 \%\end{array}$ & $\begin{array}{l}1.88 \\
81 \%\end{array}$ & 0.659 \\
\hline \multirow[t]{2}{*}{ 4-leaf stage } & $0.58 * * *$ & $0.31^{*}$ & 2.46 & 0.652 \\
\hline & $17 \%$ & $9 \%$ & $74 \%$ & \\
\hline \multirow[t]{2}{*}{ 7-leaf stage } & 0.17 NS & $0 \mathrm{NS}$ & 13.34 & 1 \\
\hline & $1 \%$ & $0 \%$ & $99 \%$ & \\
\hline \multirow{2}{*}{ 11-leaf stage } & $0.52^{*}$ & $0 \mathrm{NS}$ & 18.56 & 1 \\
\hline & $3 \%$ & $0 \%$ & $97 \%$ & \\
\hline 15-leaf stage & $0.70^{* *}$ & $0 \mathrm{NS}$ & 18.89 & 1 \\
\hline \multirow{2}{*}{ Growth rate (days/leaf) } & $\begin{array}{l}4 \% \\
0.13^{*}\end{array}$ & $\begin{array}{l}0 \% \\
0 \mathrm{NS}\end{array}$ & $\begin{array}{r}96 \% \\
0.14\end{array}$ & 1 \\
\hline & $48 \%$ & $0 \%$ & $52 \%$ & \\
\hline \multicolumn{4}{|l|}{ Enzyme loci } & $1^{* * *}$ \\
\hline \multicolumn{4}{|l|}{ Experiment 2} & \\
\hline Flowering time (days) & $\begin{array}{l}11.1^{* * *} \\
49 \%\end{array}$ & $\begin{array}{l}3.0^{* * * *} \\
13 \%\end{array}$ & $\begin{array}{r}8.8 \\
38 \%\end{array}$ & 0.787 \\
\hline \multirow[t]{2}{*}{ Number of cauline leaves } & $2.9^{* * *}$ & $1.0^{* * *}$ & 1.9 & 0.744 \\
\hline & $50 \%$ & $18 \%$ & $32 \%$ & \\
\hline \multirow[t]{2}{*}{ Number of rosette leaves } & $52.3^{* * *}$ & $7.8^{* * *}$ & 21.6 & 0.870 \\
\hline & $64 \%$ & $9 \%$ & $27 \%$ & \\
\hline \multirow[t]{2}{*}{ Rosette size (mm) } & $42^{*}$ & $103^{*}$ & 590 & 0.290 \\
\hline & $6 \%$ & $14 \%$ & $\begin{array}{l}80 \% \\
000222\end{array}$ & 0.627 \\
\hline Leaf index & $\begin{array}{l}0.00138^{* * *} \\
31 \%\end{array}$ & $\begin{array}{l}0.00082^{-1} \\
19 \%\end{array}$ & $50 \%$ & \\
\hline Microsatellites & & & & $0.639^{* * *}$ \\
\hline
\end{tabular}

NS $P>0.05,{ }^{*} 0.01 \leq P<0.05,{ }^{* *} 0.001 \leq P<0.01,{ }^{* * *} P<0.001$. 
Westerman, 1971; Abbot \& Gomez, 1989), and in marginal Japanese populations (Todokoro et al., 1995). Abbot \& Gomez (1989) found much polymorphism in English and Scottish $A$. thaliana populations using allozymes; 14 of the 16 populations studied were polymorphic. On the contrary, there seems to be a complete monomorphism at microsatellite loci within the Japanese populations in spite of large differences between them (Todokoro et al., 1995). However, within population variability was only studied in three populations with small samples. Quantitative genetic studies confirm the polymorphic structure of the English populations. There is a significant between-families component of variance in quantitative characters, and many railway populations consist of individuals differing widely in their flowering times, which suggests that there are both winter and summer annual plants in them (Jones, 1971a,b,c). Slovakian populations have been studied in terms of flowering time. Most of the populations are either winter or summer annuals, but a minority consist of both types (Cetl \& Dobrovolná, 1968). In most studied cases the heritabilities were significant in both mixed populations and those consisting of only summer annuals (Dobrovolná, 1969; Cetl \& Relichová, 1971; Cetl et al., 1973). The few monomorphic populations were from a mountain area (Cetl et al., 1973).

The emerging picture of the variability in $A$. thaliana populations coincides well with Vavilov's (1926) gene centre theory proposing a greater variability in the centre of distribution of a species compared to the periphery. Central Asia has been proposed to be the centre of greatest diversity of $A$. thaliana populations (Price et al., 1994). Both the monomorphic Scandinavian populations and the Japanese populations are at the outer range of the species distribution, whereas the East and West European populations are more central. The effects of genetic drift may be pronounced in populations in northern Europe because of small population sizes, repeated bottlenecks and low founder numbers in unfavourable environmental conditions. In Japan $A$. thaliana is a relatively recent colonizer which may in part explain the lack of intrapopulation variability.

\section{Both molecular markers and quantitative traits are widely differentiated between populations}

In spite of the lack of variation within populations, there seems to be much variation between the Scandinavian populations. The result is in agreement with the earlier studies of selfing species (Hamrick and Godt, 1990).
Comparing differentiation between populations in terms of $F_{\mathrm{ST}}$ in neutral markers to that in quantitative traits, it is possible to draw conclusions on the role of selection on the population differences (Lande, 1992). In this study the $F_{\mathrm{ST}}$-values were of similar magnitude in both quantitative traits and at marker loci. Because the differentiation was not larger in quantitative traits than at the supposedly neutral allozyme and microsatellite loci, it is not necessary to invoke selection to explain the differences between populations. On the other hand, selection cannot be excluded as an explanation. Flowering time as well as morphological traits are considered to be ecologically important.

There are several comparative studies on the population differences based on morphological and molecular traits in outcrossing plants (Schwaegerle et al., 1986; Podolsky \& Holtsford, 1995; Karhu et al., 1996; Yang et al., 1996) and animals (Prout \& Barker, 1993). These studies sometimes indicate a stronger differentiation in morphological traits than at molecular loci. Price et al. (1984) found a better agreement between similarity rankings of morphological traits and allozymes for three predominantly inbreeding plant species than for one predominantly outcrossing plant species. They related their results to the higher probability of multifocus associations in predominantly self-pollinating as opposed to outcrossing species. Our result is in line with their study.

Although usage of molecular markers as indicators of adaptations in quantitative traits must be viewed with caution, molecular markers may be good indicators of the level of genetic variability in general. An example of this are the four $A$. thaliana populations which showed within-population variability at neither molecular markers nor in quantitative traits. The lack of variation is most probably caused by a bottleneck resulting from a founder event, which reduces both additive quantitative variation and neutral variation at single loci.

\section{Is there clinal variation in flowering time?}

Clines have often been found in quantitative characteristics (Muona \& Lumme, 1977; Karhu et al., 1996), although a mosaic pattern of variation is common in inbreeding species (Allard et al., 1968). In Europe, there seems to be a change in the relative abundance of winter and summer annual $A$. thaliana populations with latitude, the summer annuals being rare in the north. Apart from the difference between summer and winter types, there is additional variation within them (Napp-Zinn,

(c) The Genetical Society of Great Britain, Heredity, 79, 144-152. 
1969). The variation found in this study is within the winter annual type. Flowering time variation was studied in three populations, and although the southernmost one flowered latest and the northernmost one earliest, no clear cline can be claimed to exist in flowering times in this sample. There are several possible explanations for not finding a cline. Environmental cues may efficiently synchronize the onset of flowering, both in the natural environment and in the greenhouse. When studying adaptation to northern conditions, seed dormancy or cold tolerance could be other relevant traits. Genotype $\times$ environment interactions are frequent in $A$. thaliana, especially with respect to flowering time (Karlsson $e t$ al., 1993) and finding the appropriate environment for the experiment may be difficult. Studying variation in reactions to environmental cues should give more concrete information on the performance of the populations. In general, too little is known about the ecology of life history variation in Arabidopsis.

\section{Acknowledgement}

We thank Timothy Prout for comments on an earlier version of the manuscript.

\section{References}

ABBotT, R. J. AND GOMEZ, M. F. 1989. Population genetic structure and outcrossing rate of Arabidopsis thaliana (L.) Heynh. Heredity, 62, 411-418.

ALlaRD, R. W., JAIN, S. K. AND WORKMAN, P. L. 1968. The genetics of inbreeding populations. Adv. Genet., 14, $55-131$.

BELL, C. J. AND ECKER, J. R. 1994. Assignment of 30 microsatellite loci to the linkage map of Arabidopsis. Genomics, 19, 137-144.

CETL, I. AND DOBRovolnÁ, J. 1968. Further data on the developmental characters of natural populations of Arabidopsis thaliana (L.) HEYNH. from Western Moravia. Arabidopsis Information Service, 5, 15-16.

CETL, I. AND RELICHOVÁ, J. 1971. Estimations of heritability in an uniform natural population of Arabidopsis thaliana (L.) HEYNH. Arabidopsis Information Service, $8,4$.

CETL, 1., MANOUSKOVÁ, Z. AND RELICHOVÁ, J. 1973. Variability and heritability of a developmental character in mountain populations of Arabidopsis. Arabidopsis Information Service, 10, 35.

CHARLESWORTH, B., MORGAN, M. T. AND CHARLESWORTH, D. 1993. Mutation accumulation in finite outbreeding and inbreeding populations. Genet. Res., 61, 39-56.

CHARLESWORTH, D. AND CHARLESWORTH, B. 1995. Quantitative genetics in plants: the effect of the breeding system on genetic variability. Evolution, 49, 911-920.

DoBrovolná, J. 1969. The estimation of heritability of developmental characters with the aid of the intraclass correlation coefficient in natural populations of Arabidopsis. Arabidopsis Information Service, 6, 20.

FALCONER, D. S. 1989. Introduction to Quantitative Genetics, 3rd edn. Longman, London.

HAMRICK, J. L. AND GODT, M. J. 1990. Allozyme diversity in plant species. In: Brown, A. H. D., Clegg, M. T., Kahler, A. L. and Weir, B. S. (eds) Plant Population Genetics, Breeding, and Genetic Resources, pp. 43-63. Sinauer Associates Inc., Sunderland, MA.

HEDRICK, P. W. 1980. Hitch-hiking: a comparison of linkage and partial selfing. Genetics, 94, 791-808.

HILlEL, J. M., FELDMAN, M. W. AND SIMCHEN, G. 1973. Mating systems and population structure in two closely related species of the wheat group. I. Variation between and within populations. Heredity, 30, 141-167.

HUltén, E. AND FRIES, M. 1986. Atlas of North European Vascular Plants North of the Tropic of Cancer, vol. 1. Koeltz Scientific Books, Königstein.

JAlas, J. 1965. Suuri Kasvikirja, vol. 2. Otava, Keuruu.

JONES, M. E. 1971a. The population genetics of Arabidopsis thaliana. I. The breeding system. Heredity, 27, 39-50.

JONES, M. E. 1971b. The population genetics of Arabidopsis thaliana. II. Population structure. Heredity, 27, 51-58.

JONES, M. E. 1971c. The population genetics of Arabidopsis thaliana. III. The effect of vernalization. Heredity, 27, 59-72.

KARHU, A., HURME, P., KARJALAINEN, M., KARVONEN, P., KÄRKKÄINEN, K., NEALE, D. AND SAVOLAINEN, O. 1996. Do molecular markers reflect patterns of differentiation in adaptive traits of conifers? Theor. Appl. Genet., 93, 215-221.

KARLSSON, B. H., SILLS, G. R. AND NIENHUIS, J. 1993. Effects of photoperiod and vernalization on the number of leaves at flowering in 32 Arabidopsis thaliana (Brassicaceae) ecotypes. Am. J. Bot., 80, 646-648.

LANDE, R. 1992. Neutral theory of quantitative genetic variance in an island model with local extinction and colonization. Evolution, 46, 381-389.

meyerowitz, E. M. AND somerville, C. R. 1994. Arabidopsis. Cold Spring Harbor Laboratory Press, New York.

MUONA, O. AND LUMME, J. 1977. Geographical variation in the reproductive cycle and photoperiodic diapause of Drosophila phalerata and D. transversa (Diptera: Drosophilideae). Evolution, 35, 158-167.

NAPP-ZINN, K. 1969. Arabidopsis thaliana. In: Evans, L. T. (ed.) The Induction of Flowering, pp. 291-304. McMillan, Melbourne.

PODOLSKY, R. H. AND HOLTSFORD, T. P. 1995. Population structure of morphological traits in Clarkia dudleyana I. Comparison of $\mathrm{F}_{\mathrm{ST}}$ between allozymes and morphological traits. Genetics, 140, 733-744.

PRICE, S. C., SHUMAKER, K. M., KAHLER, A. L., ALLARD, R. W. AND HILL, J. E. 1984. Estimates of population differentiation obtained from enzyme polymorphisms and quantitative characters. J. Hered., 75, 141-142.

PRICE, R. A., PAlMER, J. D. AND Al-SHEHBAZ, 1. A. 1994. 
Systematic relationships of Arabidopsis: A molecular and morphological perspective. In: Meyerowitz, E. M. and Somerville, C. R. (eds), Arabidopsis, pp. 7-19. Cold Spring Harbor Laboratory Press, New York.

prout, T. AND Barker,J. S. F. 1993. $F$ statistics in Drosophila buzzatii: selection, population size and inbreeding. Genetics, 134, 369-375.

ROGERS, S. O. AND BENDICH, A. J. 1989. Extraction of DNA from milligram amounts of fresh, herbarium and mummified plant tissues. Plant Mol. Biol., 5, 69-76.

SCHOEN, D. J. AND BROWN,A. H. D. 1991. Intraspecific variation in population gene diversity and effective population size correlates with the mating system in plants. Proc. Natl. Acad. Sci. U.S.A., 88, 4494-4497.

SCHWAEGERLe, K. E., garbuTt, K. ANd BAzZAZ, F. A. 1986. Differentiation among nine populations of Phlox. I. Electrophoretic and quantitative variation. Evolution, 40, 506-517.

TODOKORO, S., TERAUCHI, R. AND KAWANO, s. 1995. Microsatellite polymorphisms in natural populations of Arabidopsis thaliana in Japan. Jap. J. Genet., 70, 543-554.
VAN TREUREN, R., KUITTINEN, H., KÄRKKÄINEN, K., BAENAGONZALEZ, E. AND SAVOlainen, O. 1997. Evolution of microsatellites in Arabis petraea and Arabis lyrata, outcrossing relatives of Arabidopsis thaliana. Mol. Biol. Evol, in press.

VAvilov, N. I. 1926. Studies on the origin of cultivated plants. Bull. Appl. Bot. Leningrad, 16, 1-248.

WE1R, B. S. AND COCKERHAM, C. C. 1984 . Estimating $F$-statistics for the analysis of population structure. Evolution, 38, 1358-1370.

WESTERMAN, J. M. 1971. Genotype-environment interaction and developmental regulation in Arabidopsis thaliana. IV. Wild material; analysis. Heredity, 26, 383-395.

WRIGHT, s. 1969. Evolution and the Genetics of Populations, vol. 2, The Theory of Gene Frequencies. The University of Chigaco Press, Chicago, IL.

YANG, R.-C., YEH, F. C. AND YANCHUK, A. D. 1996. A comparison of isozyme and quantitative genetic variation in Pinus contorta ssp. latifolia by $F_{S T}$. 